\title{
Organic matter cycling in a Neotropical Reservoir: effects of temperature and experimental conditions
}

\author{
Ciclagem de matéria orgânica em um reservatório Neotropical:
} efeito da temperatura e das condiçóes experimentais

\section{Flávia Bottino $^{1}$, Maria do Carmo Calijuri ${ }^{2}$, Kevin Joseph Murphy ${ }^{3}$}

${ }^{1}$ Departamento de Hidrobiologia, Universidade Federal de São Carlos, Rod. Washington Luis, Km 235, CEP 13565-905, São Carlos, SP, Brazil e-mail: flaviabottino@yahoo.com.br

${ }^{2}$ Departamento de Hidráulica e Saneamento, Escola de Engenharia de São Carlos - EESC, Universidade de São Paulo - USP, Av. Trabalhador São-Carlense, 400, CEP 13566-590, São Carlos, SP, Brazil e-mail: calijuri@sc.usp.br

${ }^{3}$ Institute of Biodiversity, Animal Health and Comparative Medicine, Graham Kerr Building, University of Glasgow, Glasgow G12 8QQ, Scotland e-mail: kevin.murphy@glasgow.ac.uk

\begin{abstract}
Aim: This study reports a comparison between decomposition kinetics of detritus derived from two macrophyte species (Polygonum lapathifolium L.: Polygonaceae; Eichhornia azurea (Sw.) Kunth.: Pontederiaceae) growing in a neotropical reservoir (Brazil), under laboratory and field conditions, in order to assess hypotheses on the main differences in factors affecting organic matter cycling, including the effect of temperature. Methods: Plant and water samples were collected from the reservoir in August 2009. In field incubation mass loss was assessed using a litter bag technique and in the laboratory the decay was followed using a decomposition chamber maintained under controlled conditions (i.e. in the dark, at $15{ }^{\circ} \mathrm{C}$ and $25^{\circ} \mathrm{C}$ ). A kinetic model was adopted to explain and compare the organic matter decay, ANOVA (Repeated Measures) testing was used to describe the differences between the treatments and a linear correlation was used to compare in situ and in vitro experiments. Results: The mass decay was faster in natural conditions with rapid release of the labile-soluble portion. The simulated values of mineralization rates of dissolved organic matter and refractory organic matter were rapid in high temperatures $\left(25^{\circ} \mathrm{C}\right)$. The high Q10 results (mainly for $E$. azurea), and experimental conditions, and outcomes of ANOVA testing indicate the temperature variation $\left(10^{\circ} \mathrm{C}\right)$ influence the rates of mass decay. Conclusions: The results suggested rapid organic matter cycling in warm months (from October to December) supporting the microbial loop. Although the particulate organic matter losses are high in field conditions the results are of the same magnitude in both conditions suggesting an equivalence of the mass decay kinetic.
\end{abstract}

Keywords: aquatic plants, detritus, decomposition, kinetic model.

Resumo: Objetivos: Este estudo descreveu a comparação entre a cinética de decomposição in situ e in vitro dos detritos provenientes de duas espécies de macrófitas (Polygonum lapathifolium L.: Polygonaceae; Eichhornia azurea (Sw.) Kunth: Pontederiaceae) presentes em um reservatório neotropical (Brasil), com o intuito de verificar os principais fatores que afetam a ciclagem de carbono, especialmente o efeito da temperatura. Métodos: Amostras de plantas e de água foram coletadas no reservatório em agosto de 2009. Na incubação in situ a perda de massa foi avaliada utilizando-se a técnica dos litter bags. No laboratório, o decaimento de massa foi obtido em câmeras de decomposiçáo mantidas sob condiçóes controladas (i.e. no escuro, a $15 \mathrm{e} 25^{\circ} \mathrm{C}$ ). Um modelo cinético foi adotado para explicar e comparar o decaimento da matéria orgânica. Um teste ANOVA (Medidas Repetidas) descreveu as diferenças entre os tratamentos empregados e para a comparação entre os experimentos in situ e in vitro utilizou-se a correlação linear. Resultados: $\mathrm{O}$ decaimento de massa foi mais rápido em condiçóes naturais, com rápida liberação da fração lábil-solúvel. Os valores simulados dos coeficientes de mineralização da matéria orgânica dissolvida e refratária foram maiores em temperaturas altas $\left(25^{\circ} \mathrm{C}\right)$. Os elevados valores de Q10 (principalmente para E. azurea) e os resultados da ANOVA indicaram que a variação da temperatura $\left(10^{\circ} \mathrm{C}\right)$ influenciou a velocidade do decaimento de massa. Conclusóes: Os resultados sugeriram rápida ciclagem da matéria orgânica em meses mais quentes (de outubro a dezembro), favorecendo o elo microbiano. Embora a perda de massa da fraçáo particulada tenha sido maior em condiçóes naturais, os resultados apresentaram a mesma magnitude, tanto in situ como in vitro, sugerindo equivalência cinética do decaimento de massa.

Palavras-chave: plantas aquáticas, detritos, decomposição, modelo cinético. 


\section{Introduction}

Aquatic macrophytes cover extensive areas of freshwater in both natural and man-made ecosystems around the world (Bini et al., 2005; Alexander et al., 2008; Chambers et al., 2008). In tropical ecosystems, high macrophyte productivity and year round growth often lead to the development of large macrophyte standing stocks. Upon death, macrophyte decay can strongly influence physicbio-chemical conditions on aquatic ecosystems. Specifically, macrophyte decay can alter dissolved gas content due to changes in biochemical oxygen demand associated with decomposer activity, and also the release of different organic compounds during the decay process, as cellular integrity is progressively lost in senescing macrophyte tissues. These organic compounds then become a source of organic matter, for example supporting the microbial loop production process (Poi de Neiff et al., 2006).

Macrophyte detritus composition ranges from dissolved organic matter (DOM), which serves as microbial substrates; to particulate organic matter (POM) with large molecules such as cellulose, hemicelluloses and lignin (Cunha-Santino and Bianchini Junior, 2008). During decomposition, the chemical composition of the detritus changes, increasing the nitrogen concentration but decreasing the $\mathrm{C}: \mathrm{N}$ ratio and thereby improving its nutritional value and consequently influencing decay rates (Poi de Neiff et al., 2006). However the magnitude of the rates is linked to intrinsic (chemical composition of the plant; macrophyte morphological structure) and extrinsic factors (biotic and abiotic aspects such as water temperature).

The extrinsic processes which drive decomposition dynamics are important in understanding the metabolism of aquatic ecosystems. Temperature is one of the most important variables that affect the reactions and biological processes occurring during plant breakdown. Gimenes et al. (2010) gathered plant decay coefficients from temperate and tropical ecosystems and concluded that in tropical conditions temperature is the key driver of plant breakdown process since high temperatures increases the metabolism of microorganisms, thereby accelerating the rates of decomposition. However, decomposition rates are also affected by a range of other factors such as $\mathrm{pH}$, nutrients, dissolved oxygen concentration, redox potential, water level, water movement and composition of plant tissues (Best et al., 1990; Cunha-Santino and Bianchini Junior, 2006). The type of macrophyte vegetation involved also influences the decomposition process. In general floating macrophytes have the lowest decomposition rates, with faster decomposition by emergent and (especially) submerged species (Gimenes et al., 2010).

The decomposition process can result in increase in water nutrient concentrations, depletion of dissolved oxygen due to the increase in biochemical oxygen demand, and alteration of the electrical conductivity and $\mathrm{pH}$ status of the system. In addition the process increases dissolved $\mathrm{CO}_{2}$ concentration, produces humic substances, impacts on microorganism population increase in shallow waters (Silva et al., 2011), and may considerably modify energy flow in littoral zones of freshwater ecosystems (Best et al., 1990).

In order to assess the importance of the decomposition process, many studies have been performed in both in situ (litter bags), or in vitro (laboratory) conditions. (e.g. Pagioro and Thomaz, 1999; Kuehn et al., 1999; Poi de Neiff et al., 2006; Santos et al., 2009). Studies carried out under natural conditions have some drawbacks because environmental changes are not always predictable in the short term. However, in situ experiments allow for the assessment of the effect of anthropogenic interference on the decomposition process (e.g. controlling the water level of a reservoir, for example), contributing to a greater understanding of ecosystem dynamics. On the other hand, experiments under laboratory conditions are ideal to examine the interactions between specific processes and selected variables (e.g. temperature, oxygen availability, role of nutrients in microbial metabolism and consequently plant mass decay). Considering the differences in the physical, biological and chemical conditions between laboratory and environment, it is important to compare both methods and the effect of different variables on decomposition (i.e. temperature), and to examine whether an integrated approach, using both procedures may provide the optimal means of assessing questions relating to macrophyte decay and carbon cycle in tropical systems. In consequence we addressed this study using mathematical modeling of coefficient decay using both in situ and in vitro experiments. We hypothesized that the faster mass decay (contributing materials more rapidly to the organic pool) may occur under natural conditions, (i.e. under in situ experimental conditions). The effect of differing temperatures was tested under laboratory conditions in order to assess the likely 
impact of this factor on decay rates and carbon release for plants from the target reservoir.

\section{Material and Methods}

\subsection{Study area}

Itupararanga Reservoir $\left(23^{\circ} 36^{\prime} 42^{\prime \prime} \mathrm{S}\right.$ and $47^{\circ}$ 23' 48” W), São Paulo State - Southeastern Brazil (Figure 1), was built in 1912 and its storage capacity volume is about 286 million $\mathrm{m}^{3}$. The annual rainfall in the watershed is around $1,400 \mathrm{~mm}$, with dry winters and wet summers. The main uses of the water are power generation, drinking water supply and irrigation. Agriculture and riparian forest are the predominant land cover in the watershed, with $42 \%$ and $25 \%$ respectively (Garcia et al., 1999).
This study utilized plants growing in two side-arms of the reservoir: Ressaca Arm (23 $37^{\prime}$ 42.53" S and $\left.47^{\circ} 17^{\prime} 04.62^{\prime \prime} \mathrm{W}\right)$ and Paruru Arm (23 $40^{\prime} 10.7^{\prime \prime} \mathrm{S}$ and $\left.47^{\circ} 21^{\prime} 21^{\prime \prime} \mathrm{W}\right)$. The tributaries flowing into these arms run through densely populated districts of Ibiuna city with sewage input problems. Environmental data for the study sites were obtained from Bottino (2011). During the decomposition experiments the water temperature in both arms ranged seasonally from $17^{\circ} \mathrm{C}$ in the winter to $24^{\circ} \mathrm{C}$ in the summer. High dissolved oxygen concentrations in the surface layers (maximum concentration: $9.6 \mathrm{mg} . \mathrm{L}^{-1}$ in Ressaca Arm and 8.8 mg. $\mathrm{L}^{-1}$ in Paruru Arm) were recorded, decreasing lower in the water column, to a minimum at the bottom $\left(4.2 \mathrm{mg} . \mathrm{L}^{-1}\right.$ and $3.9 \mathrm{mg} . \mathrm{L}^{-1}$
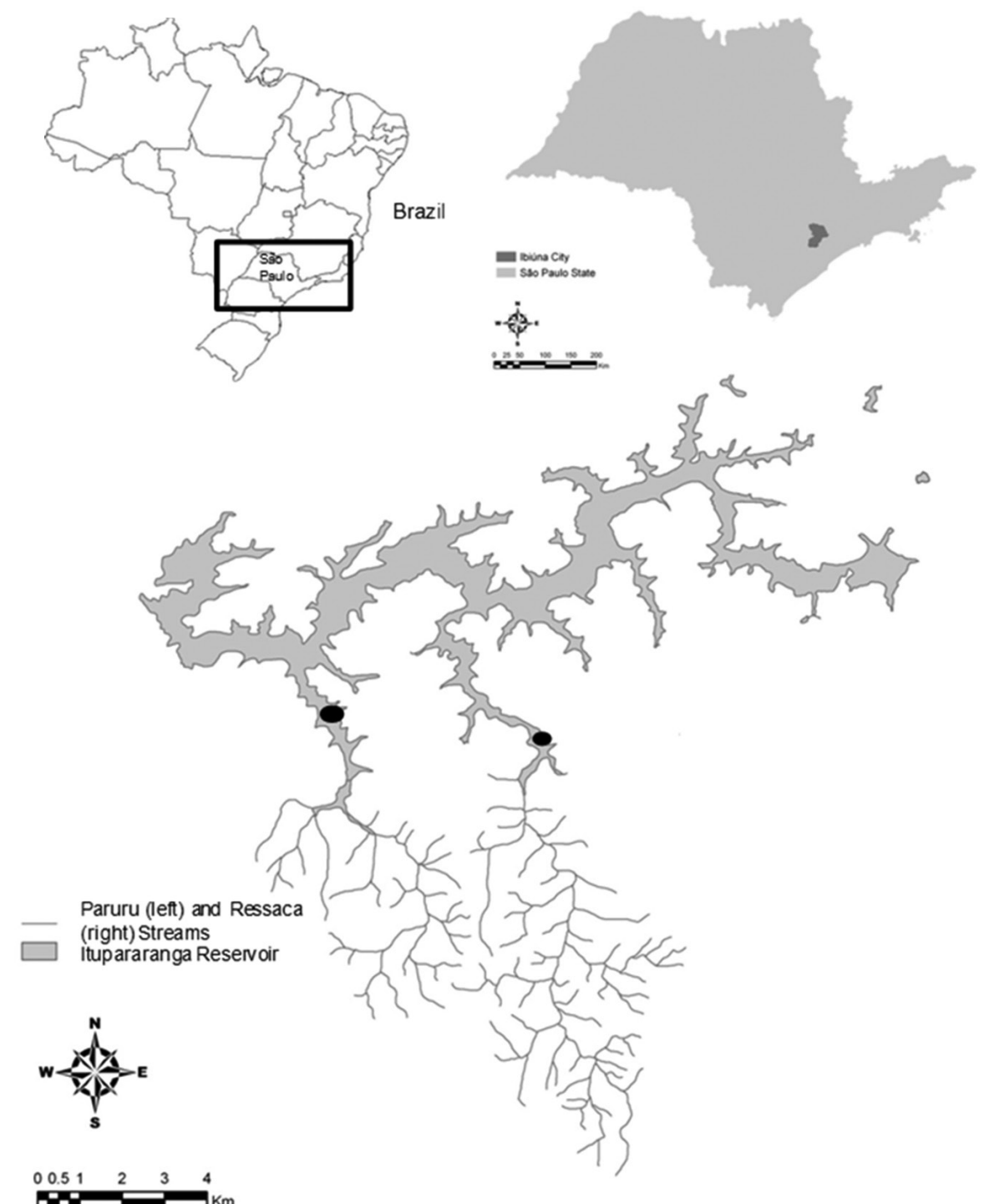

Figure 1. Location of the study area in Brazil, São Paulo State, including a map of the Itupararanga Reservoir, with the tributaries and sampling stations. 
in Ressaca and in Paruru Arms, respectively); the $\mathrm{pH}$ was between 6.6 and 7.5 in both places. The electrical conductivity was relatively low in Ressaca Arm (65-85 $\left.\mu \mathrm{S} . \mathrm{cm}^{-1}\right)$ and ranged from 41 to $102 \mu \mathrm{S} . \mathrm{cm}^{-1}$ in Paruru Arm. With regard to aquatic macrophytes in Ressaca Arm Polygonum lapathifolium L. was the predominant species and its biomass on dry-weight (DW) ranged from 407.3 to $541.5 \mathrm{~g} \cdot \mathrm{m}^{-2}$ (DW). (Bottino, 2011) Eichhornia azurea (Mart.) Solms was the main species in Paruru Arm and its biomass varied during the year from a maximum of 617 g.m $\mathrm{m}^{-2}$ (DW) down to $<50$ g.m $\mathrm{m}^{-2}$ (DW) in cold months (Bottino, 2011). During the experiments the stand areas of both macrophyte species were measured, using a GPS to obtain the stand coordinates (Bottino, 2011; Pavão, 2011). For P. lapathifolium the average stand size was $12,436 \mathrm{~m}^{2}$ in the summer (December to March) while in the winter (July and August) the stand area was 10,985 $\mathrm{m}^{2}$. For E. azurea the area ranged from $301 \mathrm{~m}^{2}$ to $1,276 \mathrm{~m}^{2}$ between winter and summer, respectively.

\subsection{Sampling and analysis procedures}

For the decomposition assessment, mature Polygonum lapathifolium and Eichhornia azurea specimens were collected randomly from the littoral zone of Itupararanga Reservoir in August 2009. In the laboratory the plants were washed with tap water to remove adhered material and were dried at $70{ }^{\circ} \mathrm{C}$ until constant weights were reached (following procedures recommended by Pagioro and Thomaz, 1999) and fragmented. For the field decomposition study, $15 \mathrm{~g}$ of dried plant material were added to litter bags (mesh size $0.5 \mathrm{~mm}: \mathrm{n}=30$ ), which were placed approximately $20 \mathrm{~cm}$ below the surface of the water where the macrophytes were collected, i.e. in the littoral zone of the reservoir (Ressaca and Paruru Arms) from August to December 2009. On predetermined days $(1,3,5,10,15,20,30,60,90$, 120 after placement in situ) litter bags were removed (randomly in triplicate), washed and oven-dried $\left(40{ }^{\circ} \mathrm{C}\right)$ to determine their POM content (ash-free: estimated following Wetzel and Likens, 1991).

To perform the experiments in controlled conditions the decomposition chambers $(n=30)$ were prepared with water samples from the reservoir and fragmented dried plants of Polygonum lapathifolium or Eichhornia azurea (following procedures recommended by Bianchini Junior and Cunha-Santino, 2011). The water samples were collected along with the macrophytes and brought to the laboratory for filtration (pore size: $0.45 \mu \mathrm{m}$ ). In each chamber, $0.5 \mathrm{~g}(\mathrm{DW})$ of plant fragment was added to $50 \mathrm{~mL}$ of previously filtered water. The chambers were maintained under aerobic conditions (with filtered air bubbling) and in the dark to avoid photo-oxidation (Bianchini Junior and CunhaSantino, 2011) at $15^{\circ} \mathrm{C}( \pm 1.5)$ and at $25^{\circ} \mathrm{C}( \pm 1.5)$. On predetermined days $(1,3,5,10,15,20,30$, $60,90,120)$ the material chambers were fractioned (in triplicate) into POM and DOM. POM was determined, as described above, and DOM was obtained using a combustion method (TOC Analyzer - Shimadzu VCPH). The inorganic matter (IM) was calculated as the difference between initial contents and remaining particulate organic matter (Bianchini Junior and Cunha-Santino, 2011). The decomposition kinetics for Labile Soluble Organic Matter (LSPOM), Dissolved Organic Matter (DOM), Refractory Organic Matter (ROM) and rates $\left(\mathrm{k}_{\mathrm{T}}\right.$ and $\left.\mathrm{k}_{4}\right)$ were calculated according to Bianchini Junior and Cunha-Santino (2011) (Equations 1 to 4 ). According to the authors the $1^{\text {st }}$ order kinetic model considers the heterogeneity of the detritus and the mass decay is assumed to occur through three pathways:

Mass loss of POM: DOM formation and oxidation of particulate fractions.

$\mathrm{dCP}_{\text {OM}} / \mathrm{dt}=-\mathrm{k}_{\mathrm{T}} \mathrm{C}_{\text {LSPOM }}-\mathrm{k}_{4} \mathrm{C}_{\mathrm{ROM}}$

where: POM: Particulate Organic Matter (\%); $\mathrm{C}_{\text {LSPOM }}$ : Change per unit time in the amount of labile and soluble compounds of POM; $\mathrm{C}_{\mathrm{ROM}}$ : per unit time in the amount of refractory compounds; $\mathrm{k}_{\mathrm{T}}$ : rate constant for the total mass loss related to leaching and oxidation of labile materials $\left(\mathrm{d}^{-1}\right) ; \mathrm{k}_{4}$ : rate constant related to the loss of mass of refractory materials $\left(d^{-1}\right)$.

Time variation of DOM.

$\mathrm{dC}_{\text {DOM }} / \mathrm{d}_{\mathrm{t}}=\mathrm{k}_{\mathrm{l}} / \mathrm{k}_{\mathrm{T}} \mathrm{C}_{\mathrm{LSPOM}}-\mathrm{k}_{3} \mathrm{C}_{\text {DOM }}$

where: $\mathrm{C}_{\mathrm{DOM}}$ : Change per unit time of DOM concentration; $\mathrm{k}_{1}$ : leaching rate constant $\left(\mathrm{d}^{-1}\right) ; \mathrm{k}_{1} /$ $\mathrm{k}_{\mathrm{T}}$ : yield coefficient of $\mathrm{C}_{\mathrm{LSPOM}}$ mass loss; $\mathrm{k}_{3}$ : DOM mineralization rate constant $\left(\mathrm{d}^{-1}\right)$.

The half time $\left(t_{1 / 2}\right)$ corresponding to the rates of various processes is calculated according to Equation 3.

$\mathrm{t}_{1 / 2}=\ln 0,5 /-\mathrm{k}$

where: k: rate constant of the process (leaching or mineralization) $\left(\mathrm{d}^{-1}\right)$.

The coefficient $Q_{10}$ expresses the metabolic dependence of organisms in relation to the temperature is estimated according to Equation 4.

$\mathrm{Q}_{10}=\mathrm{k}_{\mathrm{t} 1} / \mathrm{k}_{\mathrm{t} 2}$ 
where: $\mathrm{k}_{\mathrm{t}}$ : rate constant on the temperature 1 $\left(\mathrm{t}+10{ }^{\circ} \mathrm{C}\right) ; \mathrm{k}_{\mathrm{t} 2}$ : rate constant on the temperature 1

The 24 hours LSPOM release was obtained from difference between initial mass (day 0) and day 1 of the experiment since this process is supposed to occur in the first hours of incubation releasing soluble (DOM) and labile compounds (Bianchini Junior and Cunha-Santino, 2011). The kinetic parameters were obtained from the mathematical modeling. From the mathematical modeling results the remaining mass (POM and ROM) was accounted and we assumed the left was detritus. The contribution of both species to the organic matter input in the system was calculated using biomass data, the left detritus and original macrophyte stand area in the two arms of the reservoir (Bottino, 2011). The variation over time of POM in litter bags and in laboratory conditions (for both temperatures) was tested using ANOVA Repeated Measures (significance level $\mathrm{p}<0.05$ ) (Statistica ${ }^{\circledast}$ 10). A linear regression (Excel ${ }^{\oplus} 2007$ ) was used to compare POM data from the results of in situ and in vitro experiments

\section{Results}

From the outcome of ANOVA Repeated Measures testing the mass decay was similar between the litter bags method and laboratory assay at $15^{\circ} \mathrm{C}$ for $P$. lapathifolium and E. azurea ( $\mathrm{p}>0.05, \mathrm{~F}=3.51 ; \mathrm{p}>0.05, \mathrm{~F}=4.5$, respectively) but it was different between litter bags and laboratory assay at $25^{\circ} \mathrm{C}(\mathrm{p}<0.01, \mathrm{~F}=18.56$ for P. lapathifolium; $\mathrm{p}<0.05, \mathrm{~F}=12.48$ for E. azurea). Under laboratory conditions the mass loss at $15{ }^{\circ} \mathrm{C}$ was significantly different at $25^{\circ} \mathrm{C}$ for both P. lapathifolium and E. azurea ( $<<0.05$, $\mathrm{F}=14.83 ; \mathrm{p}<0.01, \mathrm{~F}=13.5$, respectively). After 120 days of incubation POM was the predominant remaining fraction, with $62 \%$ for both species at $15^{\circ} \mathrm{C}$ and $55 \%$ for P. lapathifolium and $59 \%$ for E. azurea in the highest temperature (Figure 2). The leaching was higher at $25^{\circ} \mathrm{C}$ during the first $24 \mathrm{~h}$, contributing for an intense mass loss (labile and soluble compounds of POM) at the beginning of the experiment (24\% for P. lapathifolium and $26 \%$ for E. azurea of which $9 \%$ and $12.7 \%$ comprise the labile portion of both species, respectively). At $15^{\circ} \mathrm{C}$ P. lapathifolium encompassed $15.0 \%$ of labilesoluble compounds of which $7.5 \%$ constitutes the soluble fraction and $7.5 \%$ comprises the labile portion. E. azurea showed $13 \%$ of labile-soluble compounds and 5.25 and $7.75 \%$ are soluble and labile fractions, respectively. As a consequence of
POM decay $\left(\mathrm{t}_{1 / 2}: 17 \mathrm{~h}\right)$, the DOM increased until between the $15^{\text {th }}$ and $20^{\text {th }}$ days, and decreased until the end of incubation, due to mineralization processes (Figure 3). In consequence the inorganic fraction continued increasing until the end of the experiments (Table 1 ).

From the results in Table 1, it is clear that the detritus of both species contained mainly refractory compounds $\left(15{ }^{\circ} \mathrm{C}\right.$ : $83.2 \%$ for $P$. lapathifolium and $84.1 \%$ for E. azurea; $25^{\circ} \mathrm{C}$ : approximately $77 \%$ for P. lapathifolium and E. azurea; 67 and $74 \%$ for P. lapathifolium and E. azurea from field experimental material) and the mineralization (driven by $\mathrm{k}_{4}$ ) was a slow pathway in both laboratory and field conditions. The rate constants $\left(\mathrm{k}_{4}\right)$ yielded the following mineralization half-time: 198 and 135 days (P. lapathifolium and E. azurea - litter bags); 240 and 266 days (P. lapathifolium and $E$. azurea $-15^{\circ} \mathrm{C}$ ); 231 and 301 days (P. lapathifolium and $E$. azurea $-25^{\circ} \mathrm{C}$ ). Although of the same order of magnitude, the mineralization coefficient of ROM in field experiment was approximately 1.2 times higher than under laboratory conditions for P. lapathifolium; while for E. azurea the field values was about 2.0 times higher in in vitro incubations. Q10 calculated from $\mathrm{k}_{4}$ values was 1.72 and 6.5 for P. Lapathifolium and E. azurea ROM mineralization, respectively.

Using the data in Table 1 the contribution of P. lapathifolium to the organic matter pool in the reservoir studied here ranged from 700 to $1,360 \mathrm{~kg}$ of organic matter (POM) in the winter and in the summer, respectively using laboratory experiment values for decay rates; while inputs estimated from values derived from field experiments ranged from 1,338 to $2,013 \mathrm{~kg}$ of POM, from same stand areas and periods. For E. azurea the contribution using lab derived values varied from 120 to $151 \mathrm{~kg}$ of POM in the winter and summer, respectively, while inputs calculated using field-derived values ranged from 219 to $582 \mathrm{~kg}$ of POM. The kinetic model fitted all experimental data with a high correlation coefficient for both POM and DOM (Table 1). The comparison of data (at equivalent time interval points in each experiment) between in situ and in vitro experiments (Figure 4) showed high coefficients of fit.

\section{Discussion}

Previous studies have noted that leaching prevails in the first phases of the decomposition process for aquatic macrophytes (e.g. Best et al., 1990; Asaeda et al., 2000; Cunha-Santino et al., 2010). 

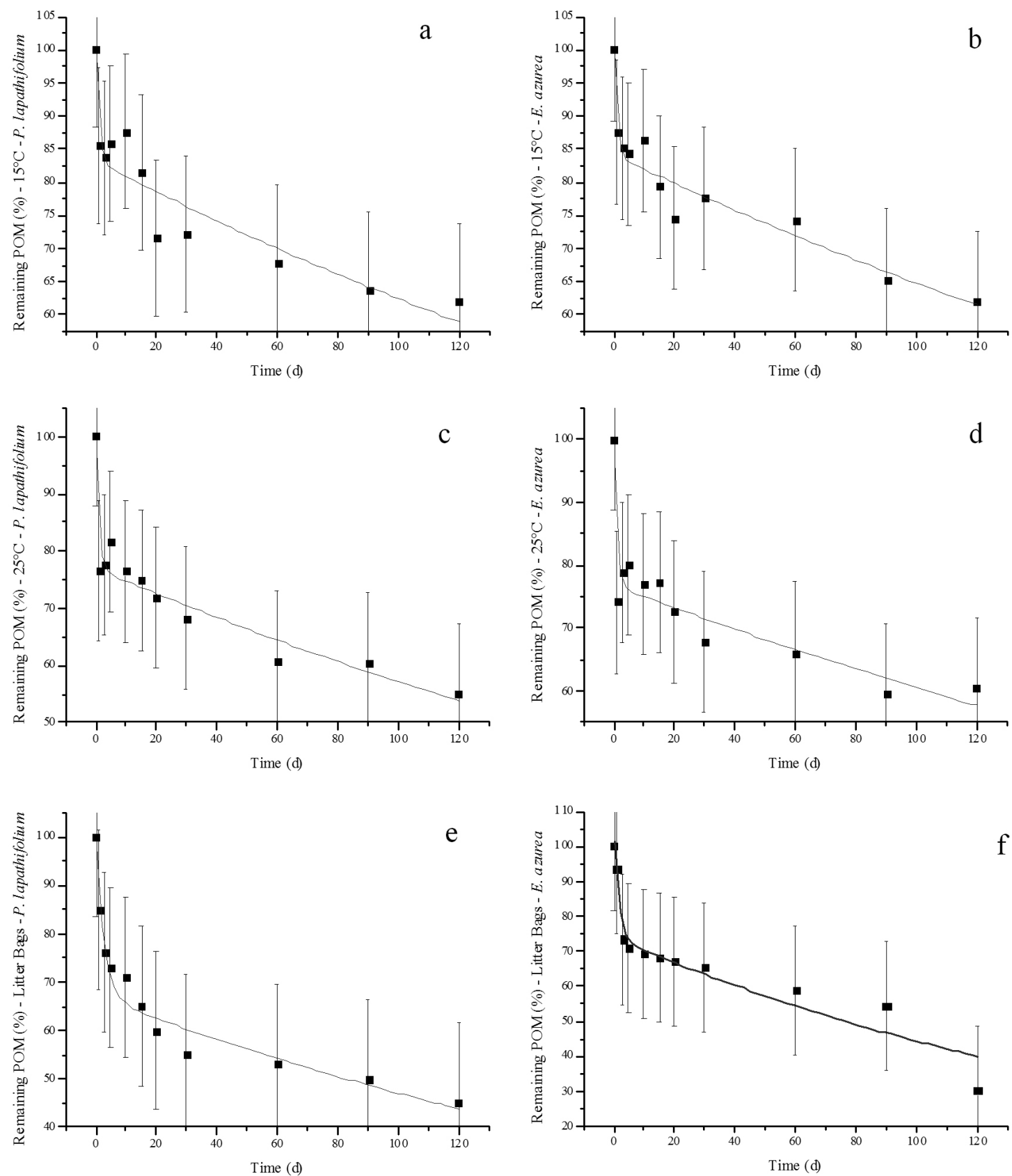

Figure 2. Field and laboratory experimental losses of POM during the decomposition of aquatic macrophytes (vertical bars: \pm standard deviation). (a) P. lapathifolium remaining POM (\%) at $15^{\circ} \mathrm{C}$; (b) E. azurea remaining POM (\%) at $15^{\circ} \mathrm{C}$; (c) P. lapathifolium remaining POM (\%) at $25^{\circ} \mathrm{C}$; (d) E. azurea remaining POM (\%) at $25^{\circ} \mathrm{C}$; (e) $P$. lapathifolium remaining POM (\%) in litter bags; (f) E. azurea remaining POM (\%) in litter bags.

The fast POM decay occurs by leaching of hydrosoluble materials and may vary from $24 \mathrm{~h}$ to 15 days (Silva et al., 2011), generating DOM. Leaching was higher at $24 \mathrm{~h}$ with both species and experimental conditions releasing high amounts of dissolved material. The highest LSPOM release occurred in the field experiment, probably due to the exposure of litter bags to abrasion, photodegradation, microbial mineralization, sedimentation and/or macroinvertebrate action any or all of which can increase the mass loss (Silva et al., 2011).

Detritus is structurally heterogeneous (in terms of chemical composition) and detrital biomass can be considered to have two main constituents: labile or refractory, according to their potential degradability (Cunha-Santino and Bianchini Junior, 2008; Bianchini Junior and Cunha-Santino, 2011). During the decomposition process, the remaining POM of both species encompassed 

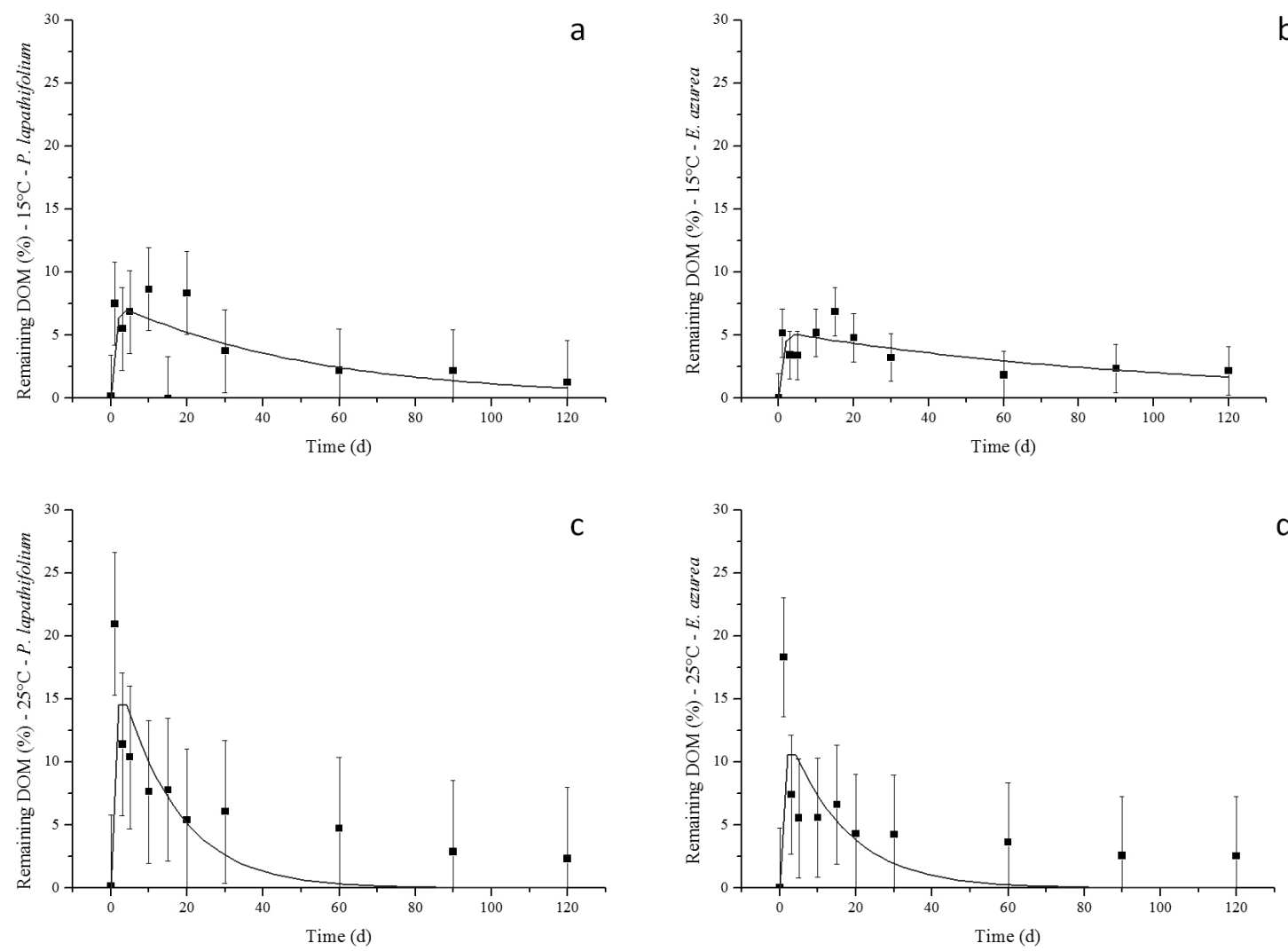

Figure 3. Laboratory experiments: mineralization of DOM during the decomposition of aquatic macrophytes (vertical bars: \pm standard deviation): (a): P. lapathifolium remaining DOM (\%) at $15^{\circ} \mathrm{C}$; (b) E. azurea remaining DOM (\%) at $15^{\circ} \mathrm{C}$; (e): P. lapathifolium remaining DOM (\%) at $25^{\circ} \mathrm{C}$; (c) E. azurea remaining DOM (\%) at $25^{\circ} \mathrm{C}$.
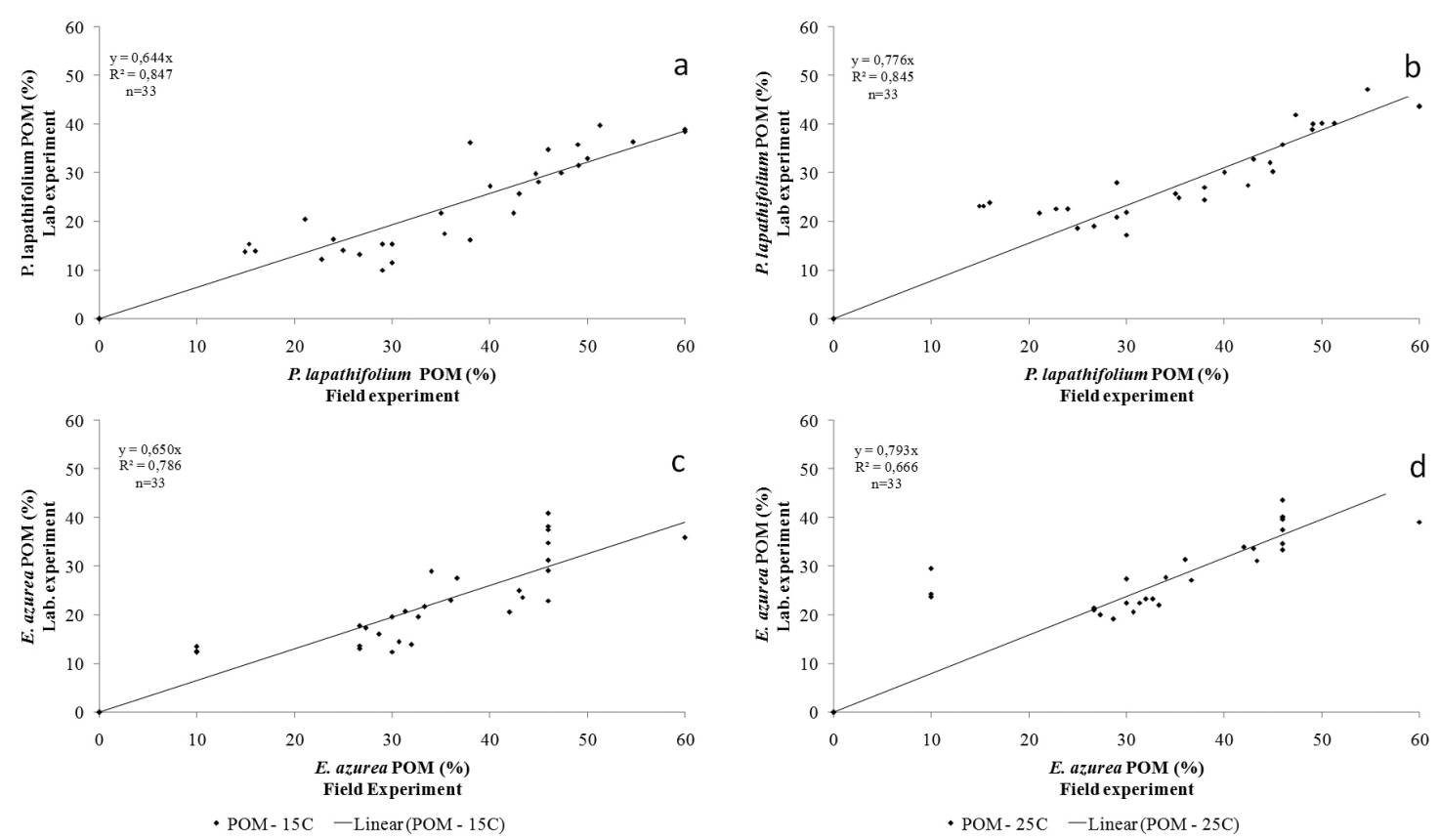

Figure 4. Relationships, obtained by regression analysis of data collected at equivalent time intervals from laboratory versus field experiments, for released Particulate Organic Matter (POM: \%) : (a) P. lapathifolium at $15^{\circ} \mathrm{C}$; (b) P. lapathifolium at $25^{\circ} \mathrm{C}$; (c) E. azurea at $15^{\circ} \mathrm{C}$; (d) E. azurea at $25^{\circ} \mathrm{C}$. 
Table 1. Results from kinetic model for both treatments (laboratory and field conditions).

\begin{tabular}{|c|c|c|c|}
\hline & $15^{\circ} \mathrm{C}$ & $25^{\circ} \mathrm{C}$ & $\begin{array}{l}\text { Litter } \\
\text { bags }\end{array}$ \\
\hline \multicolumn{4}{|l|}{ P. lapathifolium } \\
\hline LSPOM (\%) & 15.6 & 20.2 & 29.9 \\
\hline E & 4.9 & 4.4 & 4.0 \\
\hline $\mathrm{k}_{\mathrm{T}}$ & 1 & 1 & 1 \\
\hline E & - & - & - \\
\hline DOM (\%) & 7.5 & 15.2 & - \\
\hline $\mathrm{E}$ & 1.6 & 4.1 & - \\
\hline $\mathrm{k}_{3}$ & 0.018 & 0.03 & - \\
\hline$E$ & 0.01 & 0.003 & - \\
\hline$r_{2}$ & 0.70 & 0.70 & \\
\hline ROM (\%) & 83.2 & 77.0 & 67.0 \\
\hline E & 2.1 & 1.92 & 2.6 \\
\hline $\mathrm{k}_{4}$ & 0.00289 & 0.00299 & 0.0035 \\
\hline$E$ & 0.0005 & 0.0005 & 0.007 \\
\hline$r_{2}$ & 0.88 & 0.91 & 0.96 \\
\hline IM (\%) & 37.0 & 42.5 & 71.4 \\
\hline \multicolumn{4}{|l|}{ E. azurea } \\
\hline LSPOM (\%) & 15.33 & 19.27 & 27.82 \\
\hline E & 3.1 & 5.0 & 6.4 \\
\hline $\mathrm{k}_{\mathrm{T}}$ & 1 & 1 & 1 \\
\hline E & - & - & - \\
\hline DOM (\%) & 5.25 & 13.26 & - \\
\hline E & 0.7 & 4.1 & - \\
\hline $\mathrm{k}_{3}$ & 0.009 & 0.065 & - \\
\hline$E$ & 0.004 & 0.04 & - \\
\hline$r_{2}$ & 0.70 & 0.70 & - \\
\hline ROM (\%) & 84.1 & 76.8 & 73.93 \\
\hline E & 1.3 & 2.2 & 3.7 \\
\hline $\mathrm{k}_{4}$ & 0.0026 & 0.0023 & 0.0051 \\
\hline$E^{4}$ & 0.0003 & 0.0006 & 0.002 \\
\hline$r_{2}$ & 0.94 & 0.87 & 0.93 \\
\hline IM (\%) & 36.0 & 42.5 & 38.0 \\
\hline
\end{tabular}

LSPOM = Labile and soluble organic matter; $\mathrm{DOM}=$ Dissolved organic matter $\mathrm{k}_{3}=$ mineralization rate constant for DOC. $\mathrm{r}^{2}=$ coefficients from the fitting data; $\mathrm{E}=$ Error. $\mathrm{ROM}=$ Refractory organic matter; $\mathrm{IM}=$ Inorganic matter (inorganic carbon); $\mathrm{k}_{\mathrm{T}}=$ rate constant of total mass loss; $\mathrm{k}_{4}=$ rate constant of refractory compounds; $\mathrm{r}^{2}=$ coefficients from the fitting data; $\mathrm{E}=$ Error

mainly refractory compounds (i.e. supporting tissue of aquatic macrophytes). Even though ROM is a fraction characterized by slow degradation, specialized microbial populations are able to hydrolyze it enzymatically and the most important enzymes related to the decomposition are those associated with the degradation of lignocellulosic material. The amount of refractory compounds in detritus can influence differences in decomposition rates (Carvalho et al. 2005). According to Anderson and Smith (2002) plants of the family Polygonaceae have high cellulose and hemicellulose contents in stems, leading to relatively low decomposition rates.
In regard to ROM mineralization, Esteves and Barbieri (1983) found a constant rate $\left(\mathrm{k}_{4}\right)$ for $P$. ferrugineum was $0.0027 \mathrm{~d}^{-1}$ for leaves and $0.0028 \mathrm{~d}^{-1}$ for stems. In P. pennsylvanicum the relative cellulose and hemicelluloses levels increased after day 56 indicating that most of the readily decomposable material had already disappeared (Anderson and Smith, 2002). In relation to E. azurea Pagioro and Thomaz (1999) found values of $\mathrm{k}_{4}$ ranging from $0.0008 \mathrm{~d}^{-1}$ in a lotic tropical system to $0.0022 \mathrm{~d}^{-1}$ in a lentic environment, while Stripari and Henry (2002) have recorded for this species (in a tropical reservoir) values of $0.0082 \mathrm{~d}^{-1}$ and $0.0128 \mathrm{~d}^{-1}$ during dry and rainy season, respectively. Bianchini Junior (2003) gathered results from several decomposition experiments of different plants (in field and in laboratory) and the mean values for LSPOM was $26.6 \%$ and for ROM was $73.4 \%$ while constant rates were $0.76 \mathrm{~d}^{-1}$ and $0.0064 \mathrm{~d}^{-1}$ for $\mathrm{k}_{\mathrm{T}}$ and $\mathrm{k}_{4}$, respectively. The results obtained in our study work are hence in broad agreement with previous literature findings. However the coefficient values were highest when the litter bags method was used. This result is possibly due to variables such as photooxidation, hydrologic regime, temperature, oxygen availability and macro invertebrates colonization, as mentioned above.

The results for POM and ROM indicate that the decomposition of both P. lapathifolium and $E$. azurea detritus is highly likely to have both short and longer term effects in the reservoir, affecting BOD, release of nutrients, accumulation of organic matter in the sediment, gas formation and the formation of humic compounds (Best et al., 1990). The fractions responsible for the high oxygen demand have a relatively short half life period and therefore do not accumulate in the ecosystem. On the other hand the low rates of ROM mineralization can contribute to the storage of organic matter in the sediment ( $\mathrm{t}_{1 / 2}$ from 135 to 301 days), mainly when the $\mathrm{k}_{4}$ of laboratory experiments are considered. However, due to a high hydraulic retention time in Itupararanga Reservoir (from 101 days in the rainy season to 190 days in the drought period) the POM is not accumulating in the system. In tropical reservoirs seasonal influences reflect changes in water temperature and that variable is the key controlling the organic matter cycling in tropical ecosystems, the lowest temperatures in the winter (July to September in Brazil) decrease the microbial metabolism and can affect heterotrophic activity. Our results, and those of others, suggest that the most favorable season for detritus cycling is the spring (October to December in Brazil) and summer (January to March) due to higher temperatures. Although during cold months E. azurea does build 
very high biomass, in the target system reported here (and also elsewhere in Brazil: e.g. Murphy et al., 2003) the lower temperatures are not favorable for rapid detritus degradation (only $15.3 \%$ of LSPOM). ANOVA Repeated Measures testing showed that the difference in the remaining POM is linked with the temperature. The high Q10 results, mainly for $E$. azurea, indicate the influence of a critical temperature minimum of $10^{\circ} \mathrm{C}$ in relation to rates of mass decay. This is particularly important for the organic matter input from macrophyte breakdown due to microbial metabolism. Temperature is one of the most important environmental variables acting directly on organism's metabolism and influencing the heterotrofic capacity of the ecosystem (Cunha-Santino and Bianchini Junior, 2010). The breakdown process was faster under field conditions. However there is equivalence among POM mass losses between in situ and in vitro experiments, as mentioned by Silva et al. (2011). These authors pointed out that a range of external variables, as well as factors incorporated in field experimental design, are possibly contributors to enhanced mass decay in litter bags under ambient conditions, but is necessary to considerate the inherent relationships from the kinetic point of view in order to make an informed comparison of laboratory and field results.

It was expected that months with high temperatures contribute to organic matter cycling in tropical ecosystems and that such conditions are favorable to the maintenance of microbial loop processes (but it is important to consider the oxygen availability as well), whilst lower temperatures might be expected to decrease the heterotrophic potential of the ecosystem. Moreover the external variables (abrasion, photo-degradation, microbial action) acting along with internal characteristics of the ecosystem $(\mathrm{pH}$, oxygen availability, redox potential, microorganism activity) can affect the decomposition process and therefore the organic matter input in the system.

To conclude, the results produced by application of the kinetic model indicate that macrophyte decomposition under field and laboratory conditions presented rate constants (leaching or mineralization) with the same order of magnitude, suggesting equivalence between both processes. Despite this similarity the relationship among in situ and in vitro experiments showed differing slope and determination coefficients $\left(\mathrm{r}^{2}\right)$, suggesting that mass loss occurring in the reservoir is actually faster than is suggested by the results of experiments conducted under laboratory conditions. External variables, internal ecosystem characteristics even experimental procedures (e.g. oven-drying and the mesh size of litter bags) may all influence the rate of plant breakdown. Nevertheless LSPOM release rates, from both Polygonum lapathifolium and Eichhornia azurea, indicated that a high amount of carbon enters the freshwater ecosystem within $24 \mathrm{~h}$ of the commencement of the decay process.

Our results confirm, as expected, that temperature is clearly an important factor affecting organic matter cycling. In tropical reservoirs the high temperature increases heterotrophic activity and influences organic matter inputs to the ecosystem (e.g. our calculated value of $2,013 \mathrm{~kg}$ of POM from P. lapathifolium in the target neotropical reservoir). High Q10 values (>2.0) confirm the temperature effect. The fast mineralization of both DOM and ROM can cause short term effects in the system (e.g. increasing heterotrophic activity, and causing changes in $\mathrm{pH}$ and electrical conductivity). Considering that ROM degradation occurs mainly in the sediments the mineralization rates allows us to infer that reduced time detention does not cause organic matter accumulation in sediments, though further work is needed to confirm this.

\section{Acknowledgments}

We thank FAPESP for their financial support (Fundação de Amparo à Pesquisa do Estado de São Paulo, Process number 2009/50842-2), and CNPq (Conselho Nacional de Desenvolvimento Científico e Tecnológico) for scholarships (Process No. 141074/2009-4).

\section{References}

ALEXANDER, ML., WOODFORD, MP. and HOTCHKISS, SC. 2008. Freshwater macrophyte communities in lakes of variable landscape position and development in northern Wisconsin, U.S.A. Aquatic Botany, vol. 88, no. 1, p. 77-86. http://dx.doi. org/10.1016/j.aquabot.2007.08.010

ANDERSON, JT. and SMITH, LM. 2002. The effect of flooding regimes on decomposition of Polygonum pennsylvanicum in playa wetlands (Southern Great Plains, USA). Aquatic Botany, vol. 74, no. 2, p. 97 108.

ASAEDA, T., TRUNG, VK. and MANATUNGE, J. 2000. Modeling the effects of macrophyte growth and decomposition on the nutrient budget in shallow lakes. Aquatic Botany, vol 68, no. 3 p. 217-237. http://dx.doi.org/10.1016/S0304-3770(00)00123-6

BEST, EPH., DASSEN, JA., BOON JJ. and WEIGERS, G. 1990. Studies on decomposition of Ceratophyllum demersum under laboratory and field conditions: loss of dry mass and nutrients, quantitative changes in organic compounds and consequences for ambient water and sediment. Hydrobiologia, vol. 194, no. 2, p. 91-114. http://dx.doi.org/10.1007/BF00028411 
BIANCHINI JUNIOR, I. 2003. Modelos de crescimento e decomposição de macrófitas aquáticas. In THOMAZ, SM. and BINI, LM., ed. Ecologia e manejo de macrófitas aquáticas. Maringá: Eduem. p. $85-126$.

BIANCHINI JUNIOR, I. and CUNHA-SANTINO, MB. 2011. Model parameterization for aerobic decomposition of plant resources drowned during man-made lakes formation. Ecological Modeling, vol. 222, no. 7, p.1263-1271. http://dx.doi. org/10.1016/j.ecolmodel.2011.01.019

BINI, LM., OLIVEIRA, LG., SOUZA, DC., CARVALHO, P. and PINTO, MP. 2005. Patterns of aquatic macrophyte cover in Cachoeira Dourada Reservoir (GO-MG). Brazilian Jounal of Biology, vol. 65, no. 1, p. 19-24. PMid:16025899. http:// dx.doi.org/10.1590/S1519-69842005000100004

BOTTINO, F. 2011. Diversidade, Biomassa e Decomposição de Macrófitas Aquáticas no Resevatório Itupararanga. São Carlos: Universidade de São Paulo. 136 p. [Tese de Doutorado].

CARVALHO, P., THOMAZ, SM. and BINI, LM. 2005. Effects of temperature on decomposition of a potential nuisance species: the submerged aquatic macrophyte Egeria najas Planchon (Hydrocharitaceae). Brazilian Jounal of Biology, vol. 65, no. 1, p. 51-60.

CHAMBERS, PA., LACOUL, P., MURPHY, KJ. and THOMAZ, SM. 2008. Global diversity of aquatic macrophytes in freshwater. Hydrobiologia, vol. 595, no. 1, p. 9-26. http://dx.doi.org/10.1007/s10750007-9154-6

CUNHA-SANTINO, MB. and BIANCHINI JUNIOR, I. 2006. The aerobic and anaerobic decomposition of Typha dominguensis Pers. Acta Limnologica Brasiliensia, vol.18, no. 3, p. 321-334.

CUNHA-SANTINO, MB. and BIANCHINI JUNIOR, I. 2008. Carbon cycling potential from Utricularia breviscapa decomposition in a tropical oxbow lake (São Paulo, Brazil). Ecological Modeling, vol. 218, no. 2, p. 375-382.

CUNHA-SANTINO, MB., BIANCHINI JUNIOR, I. and OKAWA, MH. 2010. The fate of Eichhornia azurea (Sw.) Kunth detritus within a tropical reservoir. Acta Limonologica Brasiliensia, vol. 22, no. 2, p. 109-121.

CUNHA-SANTINO, MB. and BIANCHINI JUNIOR, I. 2010. Q10 of heterotrophic activity during anaerobic decomposition of Utricularia breviscapa and is effect on carbon cycle in a tropical lagoon. Brazilian Journal of Biology, vol. 70, no. 2, p. 317-324. http://dx.doi.org/10.1590/S151969842010000200013

ESTEVES, FA. and BARBIERI, R. 1983. Dry weight and chemical changes during decomposition of tropical macrophytes in Lobo Reservoir - São Paulo, Brazil. Aquatic Botany, vol. 16, no. 3, p. 285-295. http:// dx.doi.org/10.1016/0304-3770(83)90038-4

GARCIA, JPM., FREITAS, NP. and FILHO, NLS. 1999. Caracterização geo-ambiental da Represa de Itupararanga. Available from: <http://IPE.ibrc.unesp. br/cbhsmt/projeto.html>. Access in: Dec 2009.
GIMENES, KZ., CUNHA-SANTINO, MB. and BIANCHINI JUNIOR, I. 2010. Decomposição de Matéria Orgânica Alóctone e Autóctone em Ecossistemas Aquáticos. Oecologia Australis, vol. 14, no. 4, p. 1036-1073. http://dx.doi.org/10.4257/ oeco. 2010.1404 .13

KUEHN, KA., GESSNER, MO., WETZEL, RG. and SUBERKROPP, K. 1999. Decomposition and $\mathrm{CO}_{2}$ evolution from standing litter of the emergent macrophyte Erianthus giganteus. Microbial Ecology, vol. 38, no. 1, p. 50-57. PMid:10384009. http:// dx.doi.org/10.1007/s002489900154

MURPHY, KJ., DICKINSON, G., THOMAZ, SM., BINI, LM., DICK, K., GREAVES, K., KENNEDY, M., LIVINGSTONE, S., McFERRAN, H., MILNE, J., OLDROYD, J. and WINGFIELD, R. 2003. Aquatic plant communities and predictors of diversity in a sub-tropical river floodplain: the Upper Rio Paraná, Brazil. Aquatic Botany, vol. 77, no. 4, p. 257-276. http://dx.doi.org/10.1016/S03043770(03)00108-6

PAGIORO, TA. and THOMAZ, SM. 1999. Decomposition of Eichhornia azurea from limnologically different environments of the Upper Paraná River Floodplain. Hydrobiologia, vol. 411, no. 1 , p. 45-51.

PAVÃO, AC. 2011. Riqueza e Distribuição de Macrófitas Aquáticas no Reservatório Itupararanga, Bacia do Rio Sorocaba-SP. Sorocaba: Universidade Federal de São Carlos. 64 p. [Dissertação de Mestrado].

POI DE NEIFF, A., NEIFF, JJ. and CASCO, SL. 2006. Leaf litter decomposition in three wetland types of the Paraná River floodplain. Wetlands, vol. 26, no. 2, p. 558-566. http://dx.doi.org/10.1672/02775212(2006)26[558:LLDITW]2.0.CO;2

SANTOS, MG., CUNHA-SANTINO, MB. and BIANCHINI JUNIOR, I. 2009. Aerobic decomposition of Myriophyllum aquaticum (Vell.) Verdc. regulated by chemical composition of detritus and temperature. Acta Limnologica Brasiliensia, vol. 21, no. 3, p. 269-273.

SILVA, DS., CUNHA-SANTINO. MB., MARQUES EE. and BIANCHINI JUNIOR, I. 2011. The decomposition of aquatic macrophytes: bioassays versus in situ experiments. Hydrobiologia, vol. 665, no. 1, p. 219-227. http://dx.doi.org/10.1007/ s10750-011-0625-4

STRIPARI, NL. and HENRY, R. 2002. The invertebrate colonization during decomposition of Eichhornia azurea Kunth in a lateral lake in the mouth zone of Paranapanema river into Jurumirim reservoir (Sao Paulo, Brazil). Brazilian Journal of Biology, vol. 62, no. 2, p. 293-310. PMid:12494917. http://dx.doi. org/10.1590/S1519-69842002000200014

WETZEL, RG. and LIKENS, GE. 1991. Limnological analysis. New York: Springer-Verlag. 429 p.

Received: 12 September 2012 Accepted: 27 September 2013 